\title{
Corporate governance criteria as applied in private equity investments
}

\author{
R. Millson \\ Graduate School of Business Administration, \\ University of the Witwatersrand, PO Box 98, Wits 2050, \\ Republic of South Africa \\ Email: rmillson@furnex.co.za \\ M. Ward* \\ Gordon Institute of Business Science, \\ University of Pretoria, P.O. Box 787602, Sandton, 2146, \\ Republic of South Africa \\ Email:mike.ward@up.ac.za
}

Received March 2004

\begin{abstract}
Ineffective governance has often formed a backdrop to corporate failure with the resultant negative impact on stakeholders. In the field of private equity, investors have consistently received financial returns that outperform those of listed equities. This research investigates the relationship that private equity principals seek with their agents.
\end{abstract}

The "agent-principal” relationship in private equity investments was investigated through a literature review and a survey of experienced private equity practitioners identified the key characteristics associated with this relationship. A conjoint analytical technique was used to measure the relative importance of the various attributes and the degree of preference or utility value for these attributes amongst a sample of 27 experts.

The field research established that private equity investments are characterised by, inter alia, proactive agent-principal relationships; a relatively high level of shareholder activism; insistence on transparency; non-executive influence; and active performance management. While the implementation of these lessons may be a subject for future research, the current research has identified and prioritised corporate governance mechanisms that may be more generally applied.

*To whom all correspondence should be addressed.

\section{Introduction}

Corporate governance is a matter of current public debate, following the controversy surrounding the collapse and financial distress of many firms and the resultant impact on stakeholders. The debate revolves around matters such as disclosure of executive remuneration; irregularities in audit and financial reporting; board composition and balance between non-executive and executive directors; the scope of a director's fiduciary responsibilities; and shareholder activism. Capital markets and their representatives, and other important parties such as the media, cite ineffective governance as a major cause of corporate failure. Regulatory bodies have responded with the passing into law of regulations, such as the Sarbanes-Oxley Act in the USA, and recommendations that companies subscribe to principles detailed in various reports, including the King reports on corporate governance in South Africa and the Combined Code on Corporate Governance in the U.K.

Notwithstanding the regulatory, legal and advisory response, capital and labour interests increasingly base their funding decisions not only on the financial performance of a corporation, but also on its reputation and governance. This view is espoused by the former Chairperson of the United States Securities and Exchange Commission, Arthur Levitt (1999), and supported by Davies (1997) and Rousseau
(2001). The reputation and governance of a corporation translate into a 'governance premium', which consulting firm McKinsey \& Co. measured and found translated into higher price/earnings multiples and other improved metrics (Howell \& Hibbard, 2002). A report tabled by the Organisation for Economic Co-operation and Development (OECD) (1999) confirms this, concluding that adherence to practices of good corporate governance will help to improve the confidence of investors, may reduce the cost of capital and may induce more stable sources of capital.

Private equity partnerships provide equity capital to enterprises that are not normally listed on a stock exchange. The private equity partnership focuses on equity investments made in the early phases of a company's life cycle as well as development capital for expansion and development, and buy-out capital, including funding for management buy-outs or buy-ins (KPMG \& SAVCA, 2003). Although private firms seeking capital are not subject to stringent public disclosure requirements, there are carefully considered criteria regarding corporate governance that a private equity partnership applies in making the investment decision and governance measures that it introduces following investment.

A two-year study of private equity markets led by Dr. George Fenn, at the time of the US Federal Reserve, 
culminated in the comprehensive 1995 publication entitled 'The Economics of the Private Equity Market'. In this study, Fenn, Liang and Prowse (1995) established that, in general, firms funded through means of private equity deliver superior financial returns against most other asset classes. That private equity delivers superior returns is supported in the literature by Kaplan (1998a), Zider (1998), Campbell (2000), Datamerge (2000), Rogers, Holland and Haas, (2002) and KPMG \& SAVCA (2003).

This study investigates determinants of the agent-principal relationship that private equity partnerships seek with their portfolio companies, and in so doing identifies corporate governance lessons that can be more generally applied.

\section{Literature review}

Jensen and Meckling (1976) define the agency relationship as a situation where an individual (the principal) engages another person (the agent) to perform a service, and to this end delegates some decision-making authority to the agent. The 'Classical Objective Function' (Damodaran, 2002) details the constituencies to whom managers are responsible, including stockholders, bondholders, financial markets and society. However, Damodaran states that managers are capable of putting their own interests above those of bondholders and stockholders, delaying bad news or providing misleading information to financial markets, and incurring significant social costs on society, not all of which can be traced back to the firm.

The appointment of an agent and the ongoing relationship between agent and principal to meet the seemingly juxtaposed positions of financial performance on the one hand and governance on the other, is thus of critical importance, and one which, according to Jensen and Smith (1995), should be governed by a contract to ensure that, inter alia, the interests of the agent are aligned to those of the principal.

Agency theory can be loosely traced to Spence and Zeckhauser (1971), who provided an early analysis of the problems associated with structuring the agent's compensation to align his/her incentives with the interests of the principal. These problems were later encapsulated in what Ross (1973) described as the 'principal's problem', where the principal delegates a variable level and type of authority to the agent with the aim of generating a certain result. However, the outcomes are capricious as they are influenced by factors outside the control of both agent and principal, resulting in agents being paid for their effort, and not for the level of output. Hendry (2002) states that people are generally not perfectly honest and truthful, resulting in the 'principal's problem', which is rooted in the following assumptions:

i. People in general are self-seeking and opportunistic economic utility maximisers.

ii. The interests of principals differ from those of their agents. iii. Principals have incomplete knowledge of their agents' actions.

According to Sapienza, Korsgaard, Goulet and Hoogendam (2000), agency problems are exacerbated because the interests of management are in conflict with those of shareholders ('goal conflict'), and because shareholders have less access than management to information on which to make educated decisions regarding the performance of management ('information asymmetry'). Eisenhardt (1989) outlines the fundamental assumptions underlying agency theory:

i. There exists goal divergence between the principal and the agent.

ii. There exists hidden information either before or after the contracting of the agent.

iii. The principal and agent have different risk preferences, which may lead to different actions being taken.

Thus, within the agent-principal relationship, corporate governance deals with the question of how shareholders incentivise management to effectively align the goals of management and owner, ensure that there is sufficient information flow from agent to principal enabling the proper monitoring of management, and control management to perform in such a manner that they act responsibly. Agency theory forms the backbone to corporate governance and therefore serves as a foundation for the literature review. Goal conflict and information asymmetry are more comprehensively dealt with below.

A primary source of goal conflict between owners and outside shareholders is the separation of ownership and control (Jensen \& Meckling, 1976). In this regard, the principal faces a risk of moral hazard or opportunism on the part of the agent, who may act in a self-interested manner at the principal’s expense (Fenn et al., 1995; Kaplan, 1998a).

In a management context, moral hazard may take the form of the misappropriation of firm's resources by the agent, the simple avoidance of tasks required for the meeting of objectives, or the pursuit of selfish interests, such as career progression, rather than focusing on the needs of the firm. Short (2000) confirms this, stating that the agent's private benefit of control leads to empire building, perks, entrenchment and biased decision making. The agent may also engage in philanthropic or ethically motivated behaviour with respect to stakeholders, which may not be in the best interests of the shareholders (Hendry, 2002).

Further related to the specification of objectives is what Holmstrom and Kaplan (2001) refer to as 'multitasking', which arises because of the complex or multifaceted nature of the principal's objectives. These objectives are difficult to capture in a performance-based contract. Hendry (2002) states that in these cases, attempts to specify outcomes can be dysfunctional, as an agent will perform in such a manner as to meet specific terms of the incentives, rather than in the more general interests of their principals; i.e. the agent is rewarded according to what is specifically measured, and 
will thus perform to meet those terms exclusively. To prevent the agent misunderstanding, misinterpreting or misjudging the principal's specification of objectives, the principal needs to communicate more detailed and precise expectations, and to this end may invest in a personal relationship with the agent to improve the agent's understanding of the principal's goals and to share values and priorities underlying these goals.

According to Sapienza et al. (2000:332), in venture capitalbacked firms, goal conflict is caused by 'issues of valuation, exit timing, and the allocation of resources and effort'. Once selected and financed, company managers have incentives to follow their own agendas over those of their investors. The nature of the investment term allows for a long period in which management will be able to misuse funds at their disposal and use their own discretion.

Information asymmetry creates a problem of adverse selection and is the basis of a second agency risk facing the principal (Kaplan, 1998a). In this case the agent might lack the ability to meet the performance expectations of the principal, or, according to Hendry (2002), the agent may misrepresent his/her abilities and claim to be able to provide results they know they cannot achieve. Pfeffer (1998:113114) concurs that there are differences in perspective and preference between owners and those who work for them, and 'individuals not only pursue self-interest but do so on occasion with guile and opportunism', 'misrepresenting information and diverting resources to their personal use'.

Therefore the problems of goal conflict and information asymmetry appear inextricably linked, for without the ability to misrepresent or conceal certain information, it would be difficult to pursue goals of self-interest rather than those of the firm.

Certain insights from private equity-funded firms are explored in the financial literature, with particular focus on Leveraged Buy-Out (LBO) related governance issues. In a study of more than 2000 private equity transactions, Rogers et al. (2002) found that the secret to the top performing private equity firms lay in the rigour of the managerial discipline they exerted on the portfolio company. According to Kaplan (1998b) and Kroszner (1998), the wave of LBO-driven financial deal making in the 1980s led to the application of LBO corporate governance insights by executives, boards of directors and shareholders in the 1990s.

Private equity partnerships have evolved structures that help solve incentive and agency problems (Fenn et al., 1995; Kaplan, 1998b). According to Busenitz, Moesel and Fiat (1997), the system of monitoring and the incentives that are put into place by the principal to govern the agent will determine the degree of effort and the amount of opportunistic behaviour that the average manager will exhibit.

Managers are entrenched to the extent to which they are not subject to any degree of discipline from corporate control mechanisms. Corporate governance and control mechanisms identified by Berger, Ofek and Yermack (1998) which could impact significantly on entrenched managers include:

i monitoring by the board;

ii the size of the board (CEOs with small boards are less entrenched due to superior monitoring by these boards);

iii a significant stockholder joining the board;

iv the threat of dismissal / forced replacement of the CEO;

$\mathrm{v} \quad$ the threat of takeover (market mechanism);

vi stock or compensation-based performance incentives; and

vii a change in governance authorities with respect to managers having discretion over the level of debt in their companies.

Addressing principals' problems incurs costs associated with the time spent monitoring the principal and the purchase of information. Furthermore, the opportunistic agent will require greater compensation if rewards are contingent on uncertain outcomes vis-à-vis a salary not linked to performance (Hendry, 2002). Owners are natural candidates for monitors as they will directly benefit from improved performance. Schleifer and Vishny (1986) suggest that the larger the share, the more capable and willing the owner would be to monitor the manager.

Management incentives may take many forms. Top executives are traditionally incentivised against measures such as sales or earnings growth, but in private equity firms, the structuring of capital funding, i.e. the use of debt, and the provision of equity to management, serve as important incentives.

Fenn et al. (1995) and Kaplan (1998b) identified the following mechanisms used by private equity firms to incentivise their portfolio companies. These include:

i. imposing a strong discipline on the buy-out company via the relatively large amount of debt used to finance the transaction (typically in LBOs);

ii. the use of equity-based management compensation; and

iii. the use of market-related mechanisms, including certain exit strategies.

Berger et al. (1998), Kaplan (1998b), Rajan and Zingales (1988) and Holmstrom and Kaplan (2001) discuss the effect of added leverage on corporate governance, and the role that debt plays as an incentive to management. As the use of leverage increased in the 1980s and 1990s, management were incentivised through equity stakes such as stock options. Berger et al. (1998:61) state that those managers whose 'financial incentives are more closely tied to 
stockholder wealth will adopt more leveraged capital structures to raise the value of the company', and thereby reduce agency costs (the difference between the actual and potential value of the company).

Kaplan (1998b) states that the large amount of debt incurred in LBOs imposes a strong discipline on buy-out company management as it ensures that managers treat capital, particularly equity capital, as costly. Rogers et al. (2002) agree that treating equity capital as scarce and leveraging the balance sheet through debt adds focus to the management team. Stewart (1991:5) states that "amplifying managers' risk reward profile is one of the reasons why LBOs have so often succeeded in creating value", as 'managers are required to put down money for an equity stake that is recovered only when and if the LBO debt has been substantially repaid but which can return many times the initial investment if the restructuring is successful'.

Innovative performance measurement and compensation programmes aim to replicate the same disciplines achieved through the use and application of debt in LBOs. Examples of these compensation programmes include Economic Value Added (EVA) of consulting firm Stern Stewart, and the Boston Consulting Group's Cash Flow Return on Investment (CFROI).

Jensen and Murphy (1990) state that there is a lack of transparency concerning the CEO's activities and the investment opportunities presented to the firm. In this respect the compensation policies must be designed to give management incentives to select and implement actions that will increase shareholder wealth. Although there are other factors that influence shareholder wealth, they argue that it is appropriate to pay CEOs on the basis of shareholder wealth since that is the objective of shareholders.

Gregory’s (2000) recommendations regarding corporate governance agree that the performance-related elements of remuneration should be designed to align the interests of the management (agent) and the shareholders (principal) and to give management motivating incentives to perform at the highest level. This is a clear response to the principal problem and has the objective of aligning interests within the context of the agent-principal relationship.

Private equity partnerships have addressed issues of conflict of interest by improving transparency through monitoring and control mechanisms such that shareholders (i.e. the private equity partnership) are aware of company performance, investment opportunities and the CEO's activities. The partnerships also grant substantial equity gains to managers resulting in a convergence of objectives. A characteristic of an LBO is the provision to managers of significant equity ownership, together with the granting of extra equity based on performance resulting in a strong incentive to ensure that the business is able to repay debt and add value as soon as possible.

Kaplan (1998b) states that in general it is common for CEOs to have a $5 \%$ equity stake in a post LBO situation, and a further $10-15 \%$ divided amongst the rest of the management team. Kaplan (1989) reported that the CEO of a typical
LBO increased his/her ownership from 1,4\% prior to the LBO to $6,4 \%$ post LBO. Rogers et al. (2002) state that the management team often owns up to $10 \%$ of the total equity in their business, through either direct investment or borrowings from the private equity partnership.

In general, the right to exercise share options for management and CEOs is conditional on meeting performance targets; i.e. options may not vest or be exercised until such time as management have met specified performance benchmarks; and may only vest over a specified time period. This serves to protect the private equity partnership from two dangers: the giving away of cheap equity to managers who have not performed, and the prevention of those skills that are valuable to the future success of the company from leaving. In setting these performance targets, however, Bygrave, Hay and Peters (1999) present a caveat in that setting objectives that are too difficult to achieve may result in creative accounting and fraud as managers seek to create the perception that they have achieved the impossible.

Rogers et al. (2002) explored the performance measures used by private equity firms and found that the equity portion of managers' compensation is directly tied to the results of the managers' divisions, effectively making them owners. This differs from many public company managers who may have a stake in the parent company, and not the individual unit or division. The problem with this, according to Rogers et al. (2002:8) is that the 'stock of the parent company is not heavily influenced by the performance of any individual unit, so equity grants don't really create ownership in the unit'.

Jensen and Murphy (1990) established that the compensation of top executives in the US was relatively insensitive to the performance of their companies' stock. However, the data used for this study was for the period 1974 to 1986. More recently, Hall and Liebman (1997) found that equity-based compensation, including share options and restricted share grants, has become increasingly popular, with a more than seven-fold increase in the average annual CEO option grant from 1980 to 1994, resulting in equity compensation contributing almost $50 \%$ of total CEO compensation by 1994. Holderness, Kroszner and Sheehan (1997) concur, indicating that principals in general understand the value of incentivising management on shareholder metrics.

Private equity firms not only incentivise management of their portfolio companies to ensure that high standards of corporate governance are maintained but, as they hold substantial equity positions, are often strongly represented on the board of directors. This representation allows them to closely monitor, guide and govern the companies in which they are invested (Kaplan, 1998a; Sapienza et al., 2000; Holmstrom \& Kaplan, 2001; Rogers et al., 2002). Hendry (2002) states that the ability to give guidance will depend on the following variables:

i the number of people making up the principal - i.e. as the number of people involved decreases, so guidance becomes more feasible; 
ii the diversity of their interests: the more diverse their interests, the less likely they are to trust any one person to act on their behalf and the more likely they are to insist on a formally agreed specification; and

iii the existence of someone able to act on their behalf, e.g., a shareholder representative on the board.

The board of directors is a mechanism employed by outside shareholders to detect and correct agency problems (Walsh \& Steward, 1990) and, more specifically, it is their central purpose to protect the interests of outside investors from agency risks, which include opportunistic behaviour and misrepresentation on the part of management (Jensen \& Meckling, 1976). Sapienza et al. (2000) explored board processes in private equity-financed firms and found that they are somewhat unique, in that both insiders (i.e. founder-managers) and outsiders (i.e. investors) have significant ownership of the firm. Furthermore, this distribution of ownership is highly concentrated, which differentiates private equity-funded companies from large, often publicly held, companies where ownership is so dispersed that often neither inside nor outside directors have a significant shareholding.

Kaplan (1998b:46) found that 'unlike public company boards that were large and dominated by distant outsiders with small ownership stakes, LBO company boards were small and dominated by LBO sponsors with substantial equity stakes in the companies'. This view is supported by Rosenstein (1988), who states that boards of venture capitalist-backed firms are more active than the boards of both large, publicly held firms and small firms without VC backing. This is because the equity stakes held by both management and outside directors are likely to be substantial, resulting in the board being highly involved and influential (Wright \& Robbie, 1998) and more concerned with formation of strategy and evaluation (Pearce \& Zahra, 1991; Busenitz, Moesel, \& Fiet, 1997). Rogers et al. (2002) contend that private equity partnership representatives who sit on the boards of their portfolio companies place the shareholder at the centre of decision making, act as unsentimental owners who are involved in hiring and firing decisions, and do not hesitate to sell when the price is right. As evidence of the importance of this function, Zider (1998) found that venture capitalists spend $25 \%$ of their time serving as directors and monitors.

Bygrave et al. (1999:305) suggest the following monitoring and control mechanisms for private equity firms to reduce and maintain low levels of opportunistic behaviour amongst management:

Establish a proper understanding of the business and set out the modus operandi of the operation - as a written business plan.

i Use subscription agreements and legal documents.

ii Ensure control through effective internal audit systems.

Iii Use non-executive directors to add commercial value to portfolio companies.
The private equity partnership also addresses the lack of information symmetry through the development of expertise in accessing and evaluating potential investments, e.g., the venture capitalist that focuses on a particular industry or technology. In the case of an LBO, the private equity partnership may develop capability through experience in operations and cost cutting. Other expertise brought to bear by a private equity partnership may include a network of contacts and relationships that provide a steady stream of information regarding the industry, competitors and the firm itself, as well as other potential investments.

\section{Research questions}

Drawing from the literature, two research questions were formulated for this study:

i. The identification of important corporate governance criteria that influence the private equity investment decision, and post investment, longer-term management of that investment.

ii. Development of a methodology to quantify the relative importance of specific attributes relating to the agentprincipal relationship that are considered by private equity practitioners in their investment decision, and the preferred levels or extent of implementation of each of these mechanisms.

\section{Research methodology}

The population in this research consisted of practitioners in the private equity industry that are engaged in or have participated in reviewing companies for the purpose of private equity funding. The field study was limited to a convenience sample of participants. Senior managers, partners and directors involved in the field of private equity were interviewed. The research was progressed through various phases, as follows:

\section{Phase One: Initial Identification of Attributes}

Informal exploratory discussions were held with an expert panel comprising seven private equity executives to obtain a general understanding of the industry and clarify the investment process. These discussions served to supplement the literature review and to identify the most relevant selection of attributes for the purposes of further rating and analysis. The attributes relate to the target company under consideration, the private equity partnership itself, and the portfolio company's prospects following investment.

To reduce the complexity of the data for the purposes of conjoint analysis, Aaker and Day (1990) advise on using a maximum of five or six attributes. The listed generic attributes were therefore filtered via the interview process according to their relevance to the issues explored in the literature review vis-à-vis agency theory and corporate governance. Following the finalisation of these generic attributes, a pilot study with the same panel of experts was conducted where respondents were required to verify and rate the importance of the attributes in their investment decision-making process. 
Table 1: Identification of attributes

The six highest ranking attributes were identified as follows (in no specific order):

\begin{tabular}{|c|c|}
\hline Attribute & Explanatory notes / perspectives explored in literature review \\
\hline Governance Policies & Level of commitment to, and implementation of, documented policies such as King II \\
\hline Transparency & $\begin{array}{ll}\text { o } & \text { Shareholder involvement and activism } \\
\text { o } & \text { Information symmetry: Shareholder access to management information }\end{array}$ \\
\hline Debt: Equity Ratio & o $\quad$ Incentive mechanisms: Capital structuring, more specifically the use of debt \\
\hline $\begin{array}{l}\text { Equity Participation of Management \& } \\
\text { CEO }\end{array}$ & $\begin{array}{l}\text { o Incentive mechanisms: Capital structuring, more specifically the granting of equity and } \\
\text { convertible debt }\end{array}$ \\
\hline $\begin{array}{l}\text { Experience and Track Record of } \\
\text { Management }\end{array}$ & $\begin{array}{l}\text { o The quality and nature of the agent underpins much of the agent-principal relationship, } \\
\text { and in all panel discussions, this attribute was highlighted as being of high importance } \\
\text { and the enabler of successful implementation of governance mechanisms. } \\
\text { This attribute emphasises the skill set of the management resource and is a supposition } \\
\text { for the level of trust that shareholders can place in management. }\end{array}$ \\
\hline $\begin{array}{l}\text { Private Equity Non-Executive Board } \\
\text { Representation }\end{array}$ & $\begin{array}{ll}\text { o } & \text { Shareholder involvement and activism } \\
\text { o } & \text { Information symmetry } \\
\text { o } & \text { Board and sub committee representation } \\
\text { o } & \text { Involvement of the private equity partnership in strategy formulation }\end{array}$ \\
\hline
\end{tabular}

A further outcome of the discussions with private equity practitioners was the determination of the appropriate levels of these attributes for testing purposes. The levels of each of these attributes are shown in Appendix 1.

\section{Phase Two: Construction of Full Profile Cards via Conjoint Analysis}

Phases two and three developed a methodology to quantify the relative importance of the various criteria by requiring respondents to rate hypothetical investment scenarios using conjoint analysis, a research technique primarily applied in the field of marketing.

Conjoint analysis is a form of monotonic regression that provides a quantitative measure of the relative importance (utility) of one attribute as opposed to another (Aaker \& Day, 1990). According to Tull and Hawkins (1993), conjoint analysis comprises a set of techniques designed to measure:

i. the importance individual respondents attach to each attribute; and

ii. their degree of preference for each level of attribute.

The measurement of utility values is effectively and efficiently achieved using conjoint analysis (Bendixen, 1988). Preferences for each level of each attribute are calculated in a manner that allows for direct comparisons of an individual's preferences across attributes. According to Ward (2000:12), 'a positive utility indicates a favourable disposition to an attribute, and the magnitude of the utility indicates the importance placed upon the specific criteria'.

Typically, the investment alternatives that private equity partnerships are faced with exhibit various combinations of different levels of performance against different criteria; decision making is a thus complex process. Conjoint analysis is therefore an appropriate technique to measure preferences.
Phase Three: Ranking of Profiles via Conjoint Analysis

To establish the complexity of the process and guide the interviewer as to the mode of administration, (i.e. rating or ranking of the cards, and to establish the time taken for the survey) a ranking process was piloted on a face-to-face basis with the expert panel. The interview process also ensured that there was no ambiguity in the definition of the features or levels.

Participants were requested to rate, according to their prospects for investment, 19 hypothetical companies, each represented on a different card (including a 'hold out' card added by the researcher) out of a score of 20, with the aim of maximising the full range of the scale between 0 and 20 . This was found to be easier than a pure ranking process and in most cases there was found to be enough differentiation between the cards. In those instances where there were 'ties', respondents were asked to review the tied companies and discriminate between them. The result was a ranking of cards.

The final sample of respondents was a convenience sample selected primarily from the South African Venture Capital and Private Equity Association (SAVCA) database. The respondents were briefed on the purpose and method of the study via telephone and their participation in the research requested. Those 27 practitioners who gave their consent to participate in the study were included

Due to the complex nature of the survey tool, face-to-face interviews were used to determine the attribute rankings as far as possible, but electronic mail combined with telephone discussion was also used where respondents were geographically remote. Each of the 19 cards (Appendix 2) given to private equity respondents described a hypothetical company, listing combinations (constructed using a factorial design) of management and governance attributes concerning the company's current position and future prospects. The respondents were asked to rate and then rank the resulting companies in terms of their preference for financing that company. 


\section{Results}

The sample consisted of respondents from dedicated private equity funds, private equity divisions of investment banks, and venture capital focused companies. The designations of the respondents were generally of a senior management level, and ranged from managing director to senior consultant. Although different companies used different titles, the most frequent response was 'director', occurring eight times. All respondents had more than three years experience, the average being 11 years. The respondents were highly qualified, with a total of 48 degrees or diplomas spread amongst the 27. The academic focus of the respondents was primarily in the financial, accounting and investment fields ${ }^{1}$.

\section{The relative importance of criteria}

Following collection of the data, the raw data was captured into Conjoint Analyser software. Conjoint Analyser was used to compute the relative utility functions of each criterion and attribute. From Figure 1 below, it is evident that the experience and track record of management was most important to respondents, followed by board representation of the private equity partnership, then transparency and the debt: equity ratio. The equity participation of management was relatively unimportant to respondents.

\section{Experience and track record of management}

Private equity partnerships are particularly concerned with the strength of the management team of the respective company under review. The dominant strength of the group utility for this feature (50\%) was supported by commentary received from interviewees who emphasised that the private equity partnership was investing principally in the management team, and thus focused on the skills and competence of management as evidenced by previous levels of success and experience. Two respondents who were from private equity divisions of banks ('PE divisions of banks') stated that they were unlikely to back inexperienced management in any scenario. Although the literature review indicated the importance of management quality (principally in sections dealing with agency theory, goal conflict and management entrenchment), the extent of dominance of this feature amongst respondents was unanticipated.

Respondents indicated a strong preference (utility score of $+3,9$ ) for an experienced management team whose members have together achieved success and or have worked in the same industry before. With a utility score of $-4,9$ (the most extreme utility score of all features), it was clear that investors strongly avoid companies where the management team has little prior experience in the industry or technology.

On a sector basis, private equity divisions of banks gave the highest score to experienced management teams $(+4,5)$, with one respondent stating that significant management experience is critical. Venture capital fund managers were less concerned with prior management success $(+3,6)$, and more willing $(-4,5$ versus a utility score of $-5,1$ for the other sectors) to trust teams with little prior experience in the industry or technology.

\section{Private equity non-executive board representation}

With a group utility of $17 \%$, board representation is another critical area that concerns private equity partnerships. Private equity partnerships insist on the option to exercise power within an investee company with at least a right to board representation pro rata to investment, but have a preference to be involved in strategy formulation and to have one permanent seat on the main board as well as representation on sub-boards such as the Audit Committee and Remuneration Committee. With a utility score of $-1,6$, investors were biased against companies in which no permanent seat was offered to them. These utility scores and the importance of private equity partnership board representation in general, are supported by sections in the literature that review shareholder involvement, activism and monitoring through control mechanisms.

Although venture capitalists (VCs) were less concerned than the total group with the track record of management; they reflected a preference to be represented on boards $(+1,9$ versus $+1,3$ for banks) and were concerned with strategy formation. A negative utility of $-2,0$ for 'no permanent seat', compared to the group average of $-1,6$ was found for this function.

\section{Debt: equity ratio}

While the literature on incentive mechanisms strongly advocates the use of debt to keep management focused on meeting performance metrics, respondents gave this feature a utility score of only $9 \%$, indicating a low to medium level of relative importance. Furthermore, with a utility score of 1,4 , private equity investors reflected concern over extremely high levels of debt (where debt is between $70 \%$ and $100 \%$ of capital). This appears to be an area where South African private equity practitioners are to an extent at odds with the findings of the literature review (which focused more on higher risk practices in the USA), and greater use of leverage could be explored in South African practice.

Banks and dedicated PE Funds were found to be consistent in their use of leverage, but venture capitalists avoided imposing significant demands on management to service debt, typified by comments that the business should be stretched, not stressed, and not overburdened; an indication of the relatively high degree of risk in other operational and strategic areas. Venture capitalists thus had a positive utility of 2,0 associated with debt levels of less than $30 \%$ of capital, compared to 0,2 and 0,4 for Banks and PE Funds, respectively.

\footnotetext{
${ }^{1}$ A detailed list of companies represented by the respondents and other demographics is available from the authors.
} 


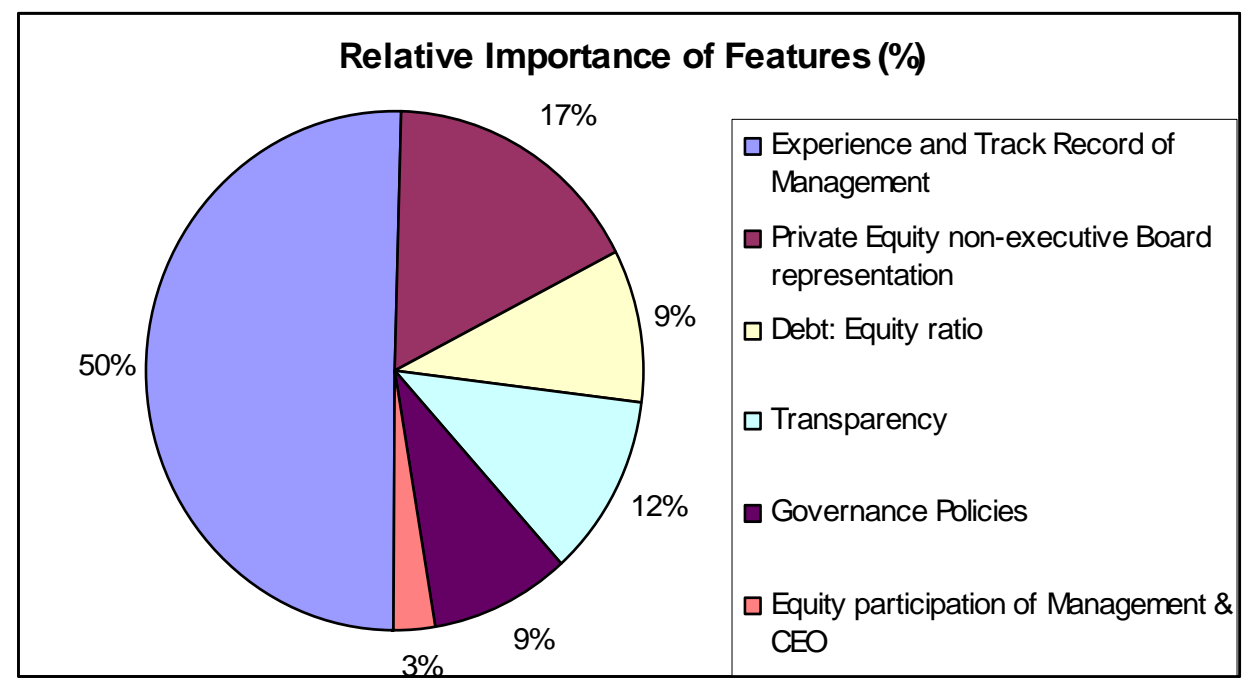

Figure 1: Relative importance of features

\section{Transparency}

With a group utility of $12 \%$, it is clear that transparency is of concern to private equity practitioners, who placed importance on regular access to management information (utility score of $+1,0$ ). Comments received highlighted that management's ability to provide timeous accounting and operational information is also seen as a reflection of the quality of their systems and processes. These findings are supported by the literature on agency theory, which emphasises information symmetry as a requirement for purposes of monitoring and control.

Dedicated PE Funds showed a particularly high need for transparency, with 'Access to monthly management accounts plus weekly review of sales and margin, plus monthly site visits and management meetings' scoring $+1,5$. In comparison, private equity divisions of banks scored only $+0,8$ and VCs only $+0,3$. One respondent commented that the need for access to monthly accounts lessens as time spent with management increases, in particular through informal meetings such as site visits.

\section{Governance policies}

Documented governance policies were not considered to be of great importance (group utility function of 9\%). Although acceptance of, and operating in accordance with, governance policies is generally advocated in the literature, the formalised documentation of policies and their integration into business planning showed a low utility $(0,7)$. This was reflected in comments suggesting that strict adherence to documented guidelines can impose unnecessary obligations on management. The level described by 'Tacit agreement on governance issues', however, generated a score of -0.8 , indicating that respondents had a negative attitude towards a mere implied acceptance of governance guidelines.

While all sectors were consistent in their disapproval of tacit acceptance of governance principles, PE Funds were significantly more demanding in ensuring that governance policies were signed, documented and integrated into business planning.

\section{Equity participation of management}

Although of perceived low importance (group utility function of 3\%), respondents preferred to allocate low levels of equity at an early investment stage (to prevent the giving away of 'cheap' equity) and identify means whereby management could increase their equity stake in the business over time through performance. As detailed in the literature, the granting of equity to management is a key incentive mechanism and generally happens as a matter of course in private equity investments. What is less defined, however, is the allocation level. Based on this research, the allotment of $10 \%$ equity up front and the option for management to ratchet this up to a total of $30 \%$ on the basis of performance reflected a preferred quantum and means of allocation.

Certain respondents commented that it was also important to establish the proportion of the executive manager's total wealth that was invested in the business - the greater the proportion, the greater the incentive to perform.

\section{Appraisal of the methodology}

Reliability in any methodology refers to the 'consistency with which a measuring instrument yields a certain result when the entity being measured hasn't changed' (Leedy \& Ormrod, 2001:31). The predictive accuracy of conjoint analysis is tested through the application of a 'hold-out' card; a card used to supplement the design generated by the programme but not required in the factorial design. The respondent's assessment of this card is 'held out' from the estimation of the utility scores, allowing the final model to be tested by predicting the respondent's rating of the holdout card. A high correlation coefficient between the predicted and actual ranking of the 'hold out' card indicates that the data and underlying assumptions are reliable. The correlation in this instance was $-0,6$, which indicated an inverse correlation. This result may have been due to the 
design of the card, but may also have been influenced by the size of the sample. It would have been better to have had more than one "hold out" card, but this would have increased the complexity of the ranking process. Despite this poor measure, the results did accord with prior expectations.

\section{Conclusions}

Private equity partnerships are primarily concerned with the strength of the management team of the respective company under review. Respondents indicated an overwhelmingly strong preference for an experienced management team whose members have together achieved success and or who have previously worked in the same industry. Conversely, investors strongly avoid companies where the management team has little prior experience in the industry or technology.

Board representation is another critical area that concerns private equity partnerships. Investors have a preference to be involved in strategy formulation and to have permanent representation on the main board, and seats on sub-boards such as the Audit Committee and Remuneration Committee.

The literature dealing with management incentive mechanisms strongly advocates the use of debt to discipline management and keep it focused on meeting performance metrics. To these ends, private equity investors utilise debt to an extent but judiciously balance this to avoid extremely high levels of debt in an effort to reduce the demands placed on management in servicing debt. There seems to be consensus between the findings of the literature review and South African investors on the need for, but not the extent of, leverage imposed. This presents an area for further study.

Transparency is of great concern to all stakeholders and especially to private equity investors, who demand regular access to management information. The research findings are well supported in the literature on agency theory, which emphasises information symmetry as a requirement for purposes of monitoring and control.

There was consistency across all private equity sectors in their disapproval of a mere tacit acceptance of governance principles as outlined in various publications dealing with principles of good corporate governance (such as those of the Cadbury Committee on Corporate Governance, 1992 and the King Committee on Corporate Governance, 2002). Dedicated private equity funds were especially demanding in ensuring that governance policies were signed, documented and integrated into business planning. This attribute was nevertheless of less overall importance relative to most other attributes.

The granting of equity to management is a key incentive mechanism to align the goals of agent and principal, and is generally employed in private equity investments. While investors prefer to allocate low levels of equity at an early investment stage, they further incentivise management through an option to increase their equity stake in the business over time following good performance.

\section{References}

Aaker, D. \& Day, G. 1990. Marketing research. 4th Edition. New York: John Wiley \& Sons.

Bendixen, M. 1988. Conjoint analysis - An exposition. Johannesburg: University of the Witwatersrand, Faculty of Business Administration. Working paper.

Berger, P., Ofek, E. \& Yermack, D. 1998. 'Why CEOs use insufficient debt.' In Dickson, T. (Ed.). Mastering finance, Great Britain: Financial Times, Prentice Hall, pp.59-64.

Busenitz, L.W., Moesel, D. \& Fiet, J.O. 1997. 'The impact of post-funding involvement by venture capitalist on longterm performance outcomes,' Frontiers of Entrepreneurial Research, [online] URL: http://www.babson.edu/ etrep/fer/papers97/. accessed 3 July 2002.

Bygrave, W.D., Hay, M. \& Peters, J.B. (Eds.). 1999. The venture capital handbook. London: Prentice Hall.

Campbell, I. 2000. 'A comparative appraisal of the South African venture capital industry'. Unpublished MBA Research Report. Johannesburg: University of the Witwatersrand.

Cadbury Committee on Corporate Governance. 1992. 'Code of best practice'. [online] URL: http://www.indiainfoline. com/nevi/cadb htm]. Accessed 8 February 2003.

Damodaran, A. 2002. 'The objective in corporate finance'. [online] URL: http://www.stern.edu. Accessed 23 March 2003.

Datamerge. 2000. 'Venture capital'. [online] URL: http://www.datamerge.com. Accessed 23 July, 2002.

Davies, P. 1997. Current issues in business ethics. London: Routledge.

Eisenhardt. K. 1989. 'Agency theory: An assessment and review', Academy of Management Review, 14: 57-74.

Fenn, G.W., Liang, N. \& Prowse, S. 1995. 'The economics of the private equity market'. [online] URL: http://www federalreserve.gov/ pubs/staffstudies/199099/ss168.pdf/. Accessed 17 July 2002.

Gregory, H.J. 2000. International comparison of corporate governance guidelines and codes of best practice: Developing and emerging markets. New York: Well, Gothal \& Manges LLP.

Hall B.J. \& Liebman, J.B. 1997. 'Are CEOs really paid like bureaucrats?’ [online] URL: http://papers.ssrn.com/sol3/ delivery.cfm/9703251.pdf/abstractid=2086. Accessed 7 July 2003.

Hendry, J. 2002. 'The principal's other problems: Honest incompetence and the specification of objectives', Academy of Management Review, 27(1): 98-114. 
Holderness, C., Kroszner, R. \& Sheehan, D. 1997. 'Were the good old days that good? Changes in managerial stock ownership since the Great Depression'. Unpublished working paper, University of Chicago.

Holmstrom, B. \& Kaplan, S.N. 2001. 'Corporate governance and merger activity in the US: Making sense of the 1980's and 1990's.' Unpublished draft paper, Massachusetts Institute of Technology, Cambridge.

Howell, J. \& Hibbard, S. 2002. 'Navigating the changed landscape of corporate governance', Harvard Management Update, 712:7-8.

Jensen, M.C. \& Meckling, W.C. 1976. 'Theory of the firm: Managerial behaviour, agency costs and ownership structure', Journal of Financial Economics, 3: 305-360.

Jensen, M.C. \& Murphy, K.J. 1990. 'Performance pay and top management incentives', Journal of Political Economy, 982:225-264.

Jensen, M.C. \& Smith, C.W. 1995. 'Stockholder, manager, and creditor interests: Applications of agency theory'. [online] URL: http://papers.ssrn.com/sol3/delivery.cfm/ SSRN_ID173461_code001011100.pdf/abstractid=173461\#P aper\%20Download. Accessed 8 July 2003.

Kaplan S. 1998a. 'Plenty of potential in private equity'. In Dickson, T. (Ed.). Mastering finance. Great Britain: Financial Times, Prentice Hall, pp.75-79.

Kaplan S. 1998b. Riding on the Benefits of the LBO Wave'. In Dickson, T. (Ed.). Mastering finance. Great Britain: Financial Times, Prentice Hall, pp, 405-410.

Kaplan, S. N. 1989. 'The effects of management buyouts on operation and value', Journal of Financial Economics, October: 217-254.

King Committee on Corporate Governance. 2002. The King Report on corporate governance for South Africa - 2002. Johannesburg: Institute of Directors.

KPMG \& The South African Venture Capital and Private Equity Association (SAVCA). 2003. Private Equity and Venture Capital Survey - 2002. Johannesburg: KPMG/SAVCA.

Kroszner, R. 1998. 'The market as international regulator'. In Dickson, T. (Ed.). Mastering finance. Great Britain: Financial Times, Prentice Hall, pp.399-404.

Leedy, P.D. \& Ormrod, J.E. 2001. Practical research: Planning and design. New Jersey: Merril Prentice Hall.

Levitt, A. 1999. 'Corporate governance in a global arena, an address to the American Council on Germany'. [online] URL:http://www.corpforms99.com/index.php?print/ id:285. Accessed 26 January 2004.

Organisation for Economic Co-operation and Development (OECD). 1999. 'Ad hoc task force on corporate governance'. SG/CG995, [online] http://www.oecd.org/ document/7/0,2340,en_2649_37439_1854919_1_1_1_3743 9,00.html, Accessed July 2003.

Pearce, J.A. \& Zahra, S.A. 1991. 'The relative power of CEOs and boards of directors: Associations with corporate performance', Strategic Management Journal, 12: 135-153.

Pfeffer, J. 1998. 'Six dangerous myths about pay', Harvard Business Review, 763:113-114.

Rajan, R. \& Zingales, L. 1988. 'Debt, folklore and financial structure'. In Dickson, T. (Ed.). Mastering finance. Great Britain: Prentice Hall, pp.53-59.

Rogers, P., Holland, T. \& Haas, D. 2002. 'Value acceleration: Lessons from private equity masters', Harvard Business Review, June: 5-11.

Rosenstein, J. 1988. 'The board and strategy: Venture capital and high technology', Journal of Business Venturing, 3: 159-170.

Ross, S. 1973. 'The economic theory of agency: The principal's problem', American Economic Review, 63: 134139.

Rousseau, L. 2001. The King Report on corporate governance. [online] URL: http://www.cm.law.za/king.htm. Accessed 8 February 2003.

Sapienza, H. J., Korsgaard, M.J., Goulet, P.K. \& Hoogendam, J.P. 2000. 'Effects of agency risk and procedural justice on board process in venture capitalbacked firms', Entrepreneurship \& Regional Development, 12: 331-351.

Schleifer, A. \& Vishny, R.W. 1986. 'Large shareholders and corporate control', Journal of Political Economy, 1: 461488.

Short, H. 2000. 'Ownership, control, financial structure and the performance of firms', Journal of Economic Surveys, 8: 203-249.

Spence, M. \& Zeckhauser, R. 1971. 'Insurance, information and individual action', American Economic Review, 61: 119-132.

Stewart, G. B. 1991. The quest for value. New York: Harperbusiness.

Tull, D.S. \& Hawkins, D.I. 1993. Marketing research, measurement and method. 6th Edition. New Jersey: Prentice-Hall.

Walsh, J.P. \& Steward, J.K. 1990. 'On the efficiency of internal and external corporate control mechanisms', Academy of Management Review, 15: 421-458.

Ward, M. 2000. 'Factors influencing credit assessment', SA Journal of Accounting Research, 141:1-19. 
Wright, M. \& Robbie, K. 1998. 'The power and functions of boards of directors', American Journal of Sociology, 5: 97111.

Zider, B. 1998. 'How venture capital works', Harvard Business Review, November-December: 131-139. 


\section{Appendix 1: Identification of attributes and levels}

Governance Policies:

i. $\quad$ strict adherence to King II, and policies documented \& integrated into business planning;

ii. governance authorities, risk and ethical policies signed by management; and

iii. tacit agreement on governance issues.

Transparency:

i. access to monthly management accounts plus weekly review of sales and margin, plus monthly site visits and management meetings;

ii. access to monthly management accounts plus informal site and management visits; and

iii. management accounts are available on request - and usually every 2 months.

Debt: Equity Ratio:

i. debt is greater than $70 \%$ of total debt plus equity, and management find it very demanding to service debt repayments;

ii. debt equals approximately $50 \%$ of total debt plus equity, and management requires focus to service debt repayments; and

iii. debt is less than $33 \%$ of total debt plus equity, and management easily service debt repayments.

Equity Participation of Management \& CEO

i. $\quad 10 \%$ equity ownership plus $20 \%$ ratchet*;

ii. $\quad 15 \%$ equity ownership plus $15 \%$ ratchet; and

iii. $\quad 20 \%$ equity ownership plus $10 \%$ ratchet.

Experience and Track Record of Management:

i. team has together attained previous private equity venture success and / or high level executive management experience in same industry;

ii. team has worked together in similar industry or technology; and

iii. team has little prior management experience in the industry or technology.

Private Equity Non-Executive Board Representation:

i. at least one permanent seat, high involvement in strategy formulation, representation on sub-boards such as Audit Committee and Remuneration Committee;

ii. $\quad$ right to board representation pro rata to investment; and the option to attend board meetings, no permanent seat.

* A ratchet is a term used in private equity that describes an option given to managers to increase their equity stake in the business according to predetermined levels of financial performance. This attribute was added after the pilot study. 
Appendix 2: Example of a rating card

\section{Company GT}

\section{Experience and Track Record of Management}

Little prior management experience in the industry or technology.

Private Equity non-executive Board representation

Right to board representation pro rata to investment.

\section{Debt: Equity ratio}

Debt $=$ approximately 50\% of total Debt + Equity, and management requires focus to service debt repayments.

\section{Transparency}

Access to monthly management accounts plus weekly review of sales and margin, plus monthly site visits and management meetings.

\section{Governance Policies}

Strict adherence to King II, and policies documented \& integrated into business planning.

Equity participation of Management \& CEO

$10 \%$ equity ownership plus $20 \%$ ratchet. 